\title{
Using the welding parameters to improve the mechanical properties of Liquefied Natural Gas storage tank welded joint
}

\author{
Abd El Fattah Mustafa Khourshid ${ }^{\mathbf{1}}$, Mohamed Ahmed Ghanem ${ }^{2}$ \\ ${ }^{1}$ Head of Production Engineering and Mechanical Design Department, Faculty of Engineering - Tanta \\ University. \\ ${ }^{2}$ PHD student. Production Engineering and Mechanical Design Department, Faculty of Engineering - Tanta \\ University.
}

\begin{abstract}
The increase demand for $L N G$ as alternative of conventional oil fuel and due to the risk assessment of $L N G$ tank. The increase of focus has been put on the performance of welded LNG tank .

Where the improvement of $9 \% \mathrm{Ni}$ steel plates mechanical properties is still continued by steel making to reduce the cost of fabrication of LNG storage tank and to give more safe structure. These applied by development of heat treatment process that change from quenched till reach to double quenched and tempered. The problem in welded joint is to be more match to mechanical properties of base metal especially with no facility of applying $P W H T$ process .

The only way to enhanced the mechanical properties of welded joint by controlling the parameters of using welding process. From the main variables of the arc welding process are the heat input and interpass temperature where the two variables control the thermal cycle of welding process.

But there are limitations on the heat input and interpass temperature. The limitations of the welding parameters are greater as the strength of the parent metal increases. Where using the too high heat input as well as high interpass temperature that produce welded joint with low tensile strength, low hardness and low toughness mechanical properties. Although the low heat input or low interpass temperature increase the susceptibility of existing hydrogen crack.

The combination of welding parameters, notably interpass temperature, are identified for SMAW process of a $9 \% \mathrm{Ni}$ steel plates to improve the zones of welded joint strength and toughness properties. Results showed that for thin test specimen, the heat input range from 1.4 to $2 \mathrm{Kj} / \mathrm{mm}$ and controlling interpass temperature within $80^{\circ} \mathrm{C}$ give high tensile strength and improve the toughness properties of welded joint and the ductility improve reduce the probability of brittle fracture happened.
\end{abstract}

Key Words: 9\%Ni steel plate, LNG tank, Heat Input,Toughness ,Tensile strength

ABBREVIATION

LNG-Liquefied Natural Gas ,HAZ- Heat Affected zone , W.M -weld metal , H.I -Heat Input N Nitrogen . C-Carbon, NI-Nickel, SMAW Shield Metal Arc Welding

\section{Introduction}

Changes in the energy situation since the worldwide oil crisis have brought about a sharp increase in the demand for LPG and LNG and successive construction of their loading and receiving bases and lowtemperature tankers for their transportation For the construction of welded structures for low-temperature service which have to undergo severe operating conditions, not only the steels to be used, but also all their weldments, must have excellent low-temperature notch toughness such as austenitic stainless steel ,aluminum and $9 \% \mathrm{Ni}$ steel [ 1-2].For example Liquefied Natural Gas (LNG) Methane will liquefy at $-163^{\circ} \mathrm{C}$ and is therefore stored or transported around $-170^{\circ} \mathrm{C}$. At this low temperature quenched and tempered $9 \%$ nickel steels have the fracture toughness and crack arrest properties required for safe construction of tanks and vessels [3]. Combination of high strength and good toughness is essential for the steels used in liquefied natural gas epically there is a high risk assessment of probability of leakage done.[4].The excellent low temperature notch impact properties of 9\% nickel steels arise from the fine grained structure of tough nickel-ferrite free from embrittling carbide networks. The optimum microstructure and mechanical properties are obtained by a carefully controlled heat-treatment in the production of the steel.The weldability of $9 \%$ nickel steel is excellent and the steel is not susceptible to cracking and shows little or no detoriation of the properties by the heat inputs normally used during the welding with procedures. Heat input should not exceed $3 \mathrm{~kJ} / \mathrm{mm}$ and interpass temperature must be limited to max $100-150^{\circ} \mathrm{C}[1-2 \& 4]$. These unique properties of the $9 \% \mathrm{Ni}$ steel plates have resulted from the microstructure where consist mainly from fine martensite and from 5-15\% retained austenite. This microstructure is existing due to quenching and tempering [5-7].The welding is widely used in construction these 
applications, controlling the parameters which affect the weldability of $9 \% \mathrm{Ni}$ steels is critical to the successful implementation of these engineering materials [8].

The strength and toughness required for the weld metal differs greatly depending upon the application for which the structure is employed and according to the type of steel and welding materials. In addition, in the fabrication of structures, a variety of welding processes are employed such as submerged arc welding (SAW), gas shield arc welding and manual welding (SMAW); however, depending upon the welding processes the thermal conditions differ greatly up to the time when the weld metal is formed, solidifies and is cooled. The properties will differ according to the difference in welding conditions and especial without the postweld heat treatment (PWHT) even when identical welding processes and welding materials are employed. [9].

Both strength and toughness are critical properties since failure may occur through either ductile rupture or fracture. The combination is important since strength and toughness have an inverse relation to one another; an increase in strength at given temperature almost invariably leads to a decrease in fracture toughness. While there is no reliable quantitative theory of the strength - toughness relation of structural alloys[10] .

The concept of Welding Mechanics was coined in 1993 to focus on the strong relationship between mechanical and fracture properties of weldments [11]. .

For such inhomogeneous systems, measurement of the toughness alone has little meaning if it is not related to the tensile properties of the material system. It has been demonstrated that the apparent fracture toughness of the same HAZ microstructure can be changed dramatically by just changing the tensile properties in the adjacent weld metal [12].

If high heat input welding is used, the HAZ can be significantly weakened due to high temperatures and slower cooling rates. However, the requirement does not universally apply to all quenched and tempered steels. The cooling rate is a primary factor that determines the final metallurgical structure of the weld and heat affected zone (HAZ), and is especially important with heat-treated steels. When welding quenched and tempered steels, for example, slow cooling rates (resulting from high heat inputs) can soften the material adjacent to the weld, reducing the load-carrying capacity of the connection.[13]

Weldment toughness tends to deteriorate with increase in welding heat input. It is said that this tendency is caused by the austenite grain growth at the heat-affected zone (HAZ) during the welding thermal cycle.[ 14-15]

Although With the increase of heat input, the impact toughness of weld zone and heat affected zone decrease, whereas the tensile strength of the weld joints does not change at all [16].

Under different weld heat inputs, the impact energy of the HAZ has a larger difference, indicating a tendency for a change in the fine structure of the HAZ. By controlling weld heat input $=20 \mathrm{~kJ} / \mathrm{cm}$, the presence of carbide in the HAZ can be removed, and therefore the impact toughness in this zone can be assured[13,14] A specific maximum interpass temperature in welding procedure is sometimes required e.g., in order to avoid hot cracking. In this case using a higher interpass temperature will increase the time spent in the critical temperature range [17-18]. This is also an issue with high strength steel weld metals but using a high interpass temperature normally plays a more important role. Longer cooling times allows hydrogen diffusion from the weld and is a major factor when avoiding hydrogen cracking [19].

As interpass temperature is increased, the main microstructural effect is that the amount of columnar structure within a reheated weld bead is reduced and an increase in the amount of re-austenitised and tempered areas is seen especially within the central beads of a welded joint. Little effects are seen on the cross sectional area of each weld bead deposited with increase in interpass temperature but the proportion of recrystallised area increases [20]. By eliminating the columnar microstructure, hardness becomes more uniform and is reduced. There is also a reduction in strength by increasing interpass temperature however toughness at low temperatures increases. To conclude, control of welding parameters such as interpass temperature is important. The Recent work [21] analyzed the variation of mechanical properties of high strength weld metals and concluded that variations in yield strength were not alone due to compositional variations, but also to process parameters such as the weld metal interpass temperature. Previous investigations have demonstrated the effective welding parameters on both of weld metal and heat affected zones as a function of the cooling rate from peak temperature[22-25]. Consequently, it concern on the improving of the toughness properties and the microstructure of welded joint to be in good condition by using heat input in the range from $1-3 \mathrm{KJ} / \mathrm{mm}$ and the interpass temperature no more $150{ }^{\circ} \mathrm{C}$ with specimens thickness more than $20 \mathrm{~mm}$. More recent work identified that heat input affects on the microstructure to improve the toughness of welded joint by controlling the cooling rates and creates types of ferrite phase and the effect of creation of ferrite types on the tensile strength of welded joint. [26-28]. However, this paper concern on heat input and interpass temperature as the main factors for affecting the embrittlement of weld joints, when the heat input is in suitable range and controlling the interpass temperature the in order to improve the tensile strength and toughness properties of welded joint . By using shield metal arc welding process with heat input rang from 1.3-2.5 KJ/mm , interpass temperature within $80 \mathrm{C}^{\circ}$ and test specimens of $9 \% \mathrm{Ni}$ steel plate with thickness $6,10 \& 14 \mathrm{~mm}$ in vertical position . 
A- Base metal

\section{Experimental Procedure}

The SA 553 type $1(9 \% \mathrm{Ni})$ steel is the used material for the liquefied natural gas (LNG) tank application. Its microstructure content from martensite and retained austenite about (5 to $15 \%$ of structure size) as shown in (Fig 1), so this posses tensile strength range from 620 to $850 \mathrm{MPa}$, impact energy at $-196 \mathrm{C}^{\circ}$ reach to $100 \mathrm{j}$ and more. [29].

The test specimens are three crews with different thickness size 6,10 and $14 \mathrm{~mm}$ thickness. The chemical and mechanical properties of $9 \% \mathrm{Ni}$ steel plate according to standards and the actual used according to material certificate as shown in table $1 \& 2$ [30].

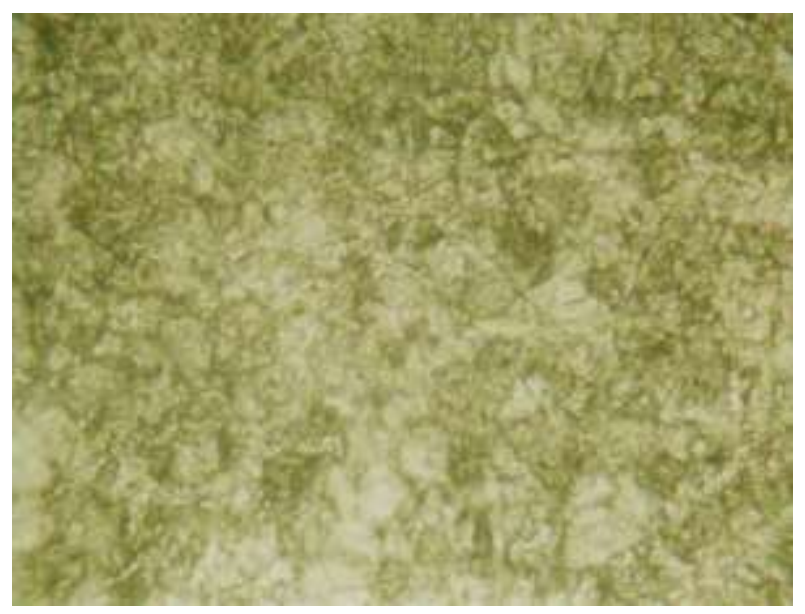

Fig 1 Present the microstructure of $9 \% \mathrm{Ni}$ steel plate

Table 1 The chemical composition of $9 \% \mathrm{Ni}$ steel according to standards and the actual of the used plate specimens

\begin{tabular}{|c|l|l|l|l|l|l|l|l|l|l|l|}
\hline Designation & \multicolumn{9}{|c|}{ Chemical composition (\%) } \\
\cline { 2 - 11 } & $\mathrm{C}$ & $\mathrm{Mn}$ & $\mathrm{Si}$ & $\mathrm{P}$ & $\mathrm{S}$ & $\mathrm{Ni}$ & $\mathrm{Mo}$ & $\mathrm{Cr}$ & $\mathrm{Ti}$ & $\mathrm{Cu}$ & $\mathrm{Nb}$ \\
\hline A553 Type I & $\leq 0.13$ & $\leq 0.9$ & $0.15-$ & $\leq 0.035$ & $\leq 0.04$ & $\begin{array}{l}8.5- \\
0.3\end{array}$ & 0.12 & 0.3 & 0.03 & 0.4 & 0.02 \\
\hline $\begin{array}{c}\text { Test specimen } \\
\begin{array}{c}10 \text { \& } 14 \mathrm{~mm} \\
\text { thickness }\end{array}\end{array}$ & 0.05 & 0.56 & 0.25 & 0.002 & 0.001 & 9.18 & 0.01 & 0.01 & 0.002 & 0.01 & 0.001 \\
\hline $\begin{array}{c}\text { Test specimen } \\
6 \text { mm thickness }\end{array}$ & 0.06 & 0.55 & 0.2 & 0.004 & 0.001 & 9.11 & 0.1 & 0.02 & 0.005 & 0.01 & 0.004 \\
\hline
\end{tabular}

Table 2 the mechanical properties of $9 \% \mathrm{Ni}$ steel according standards and actual parent metal

\begin{tabular}{|c|c|c|c|c|c|}
\hline Specification & Y.S. [R.T * ] & UTS [R.T * $]$ & El.5d $\left[20^{\circ} \mathrm{C}\right]$ & \multicolumn{2}{|c|}{$\mathrm{Kv}\left[-196^{\circ} \mathrm{C}\right]$} \\
\hline ASTM A553-1 & $\geq 585$ & $690-825$ & $\geq 20.0$ & $\begin{array}{ll}\mathrm{KV}_{\mathrm{T}} \geq 27 \mathrm{~J} & \mathrm{Kv}_{\mathrm{I}} \geq \\
\end{array}$ & Exp $>0,381 \mathrm{~mm}$ \\
\hline $\begin{array}{c}\text { Test specimen } * * \\
14 / 10, \mathrm{~mm}\end{array}$ & 665 & 715 & 44 & $\mathrm{~K} \times-205-226-236$ & $1.7-1.72-1.76$ \\
\hline $\begin{array}{c}\text { Test specimen } \\
6 \text {. mm }\end{array}$ & 650 & 700 & 34 & $\mathrm{~K} x-34-40-40$ & $1.41-1.56-1.54$ \\
\hline
\end{tabular}

R.T* Room Temperature

** Test specimen chemical and mechanical properties according to material certificate of base metal

\section{B-The Welding process}

Welding with stick electrodes however, is still a very flexible and viable process for welding under site conditions, all positions and all materials. A respected economy is also offered when using high recovery electrodes. 
So by using SMAW as welding process, electrode E NiCrFe4 with 2.5 , 3.2and $4.0 \mathrm{~mm}$ diameter to weld SA553 type I steel test specimen with thickness 6,10 and $14 \mathrm{~mm}$. The interpass temperature controlled to no more than $80 \mathrm{C}^{\circ}$ with using low ampere and increasing the travel speed to reduce the heat input.

The chemical composition and mechanical properties of electrode ENiCrFe4 according to construction code standard and actual electrode certificates as shown in Table 3, and 4 [31]

Table 3 The chemical compositions of ENiCrFe4 from code and actual values

\begin{tabular}{|c|c|c|c|c|c|c|c|c|c|c|c|c|}
\hline$\underset{\mathbf{n}}{\text { Designatio }}$ & $\mathrm{C}$ & $\mathrm{Mn}$ & $\mathrm{Fe}$ & $P$ & $\mathrm{~S}$ & $\mathrm{Si}$ & $\mathrm{Cu}$ & $\mathrm{Ni}$ & $\mathrm{Cr}$ & $\begin{array}{c}\text { Nb Plus } \\
\mathrm{Ta}\end{array}$ & Mo & $\begin{array}{c}\text { Other } \\
\text { Element } \\
\text { s Total }\end{array}$ \\
\hline $\begin{array}{c}\mathrm{ENiCrFe} 4 \\
{[21]} \\
\text { standard }\end{array}$ & 0.2 & $\begin{array}{l}1.0- \\
3.5\end{array}$ & 12 & 03 & .02 & 1.0 & 0.5 & $\begin{array}{c}60 \\
\min \end{array}$ & $13-17$ & 1.0 to 3.5 & $\begin{array}{c}1.0 \text { to } \\
3.5\end{array}$ & 0.50 \\
\hline $\begin{array}{l}\text { Weld } \\
\text { metal }\end{array}$ & 0.09 & 2.66 & 11.08 & 0.01 & 0.002 & 0.26 & 0.02 & 65.52 & 15.79 & 1.76 & 2.57 & 0.238 \\
\hline
\end{tabular}

Table 4 The mechanical properties as standard and actual value of ENiCrFe4

\begin{tabular}{|l|l|l|l|l|}
\hline & Test temperature & Tensile strength & Yield strength & Elongation (\%) \\
\hline EniCrFe4 (21) & Room temp. & $660(\mathrm{Min}.) \mathrm{MPa}$ & $360(\mathrm{Min}) \mathrm{MPa}$ & $20(\mathrm{Min})$. \\
\hline All weld metal & $20^{\circ} \mathrm{C}$ & $689 \mathrm{MPa}$ & $419 \mathrm{MPa}$ & 41.7 \\
\hline
\end{tabular}

The geometry of welded joints as shown in (Fig 2) with different root opening according to the using of electrode diameter.

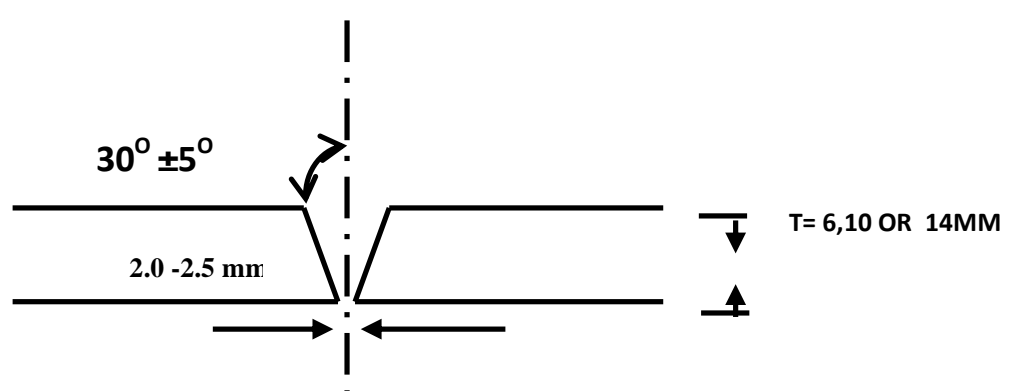

Fig 2 The joint shape for different thickness $(6,10 \& 14 \mathrm{~mm})$

\section{C- The mechanical tests}

- Tensile tests have been done on 2 test samples from each welded joint. The test conducted according to the requirements of ASME IX [32]\& ASME II part A, SA 370 [30] at room temperature and the samples shape with dimensions as shown in (Fig 3).

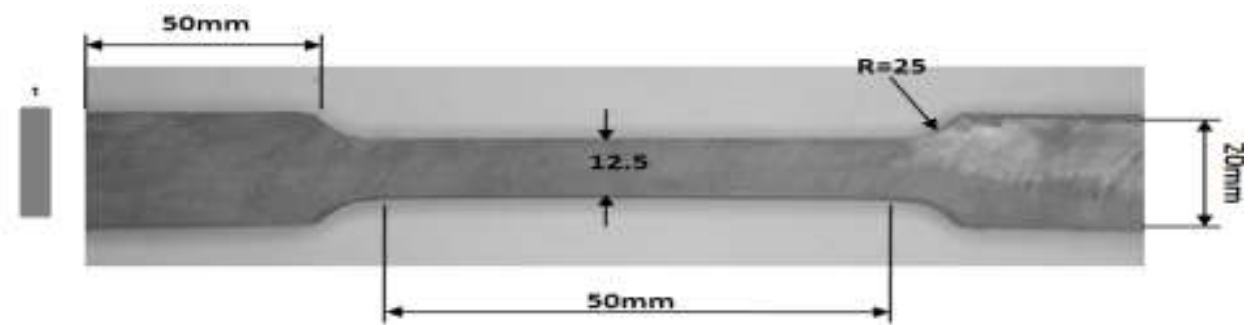

Fig 3 The test sample of tensile stress.

- Bend tests applied on 4 test samples from each welded joint with keeping in the consideration the requirements of ASME IX \&ASME II part A, SA370 (2 test samples for root bends and 2 for face bend)

- Charpy impact tests have been done in two zones of welded joint weld metal and HAZ zones , 3 test samples for each zone according to ASME IX \&ASME II part A, SA370 .The test temperature at -196 ${ }^{\circ} \mathrm{C}$.

- $\quad$ Lateral expansion test conducted according to ASME IX \&ASME II part A, SA370. 


\section{A-Tension tests}

\section{Results And Discussion}

The tensile properties of the specimens obtained from the welded joints with three different heat input levels are shown in Fig 4 to Fig 6. The tensile test results show that although the using different heat input levels that tensile strength values are above $690 \mathrm{MPa}$, which is higher value than the material tensile strength standard.

By using the next equation to calculate the cooling rate depend on the heat input have been used during the welding of test specimen [33].

Where :

$$
\begin{aligned}
& \text { Coated electrode arc welding } \\
& S=\frac{1.35 \cdot J^{1.5}}{\left(600-T_{0}\right)^{2}\left\{1+\frac{2}{\pi} \tan \cdot^{-1}\left(E \mathrm{t} \cdot \frac{1}{6} \frac{14.6}{6}\right)\right\}}
\end{aligned}
$$

\section{$S$ : Cooling ratio from $800^{\circ} \mathrm{C}$ to $500^{\circ} \mathrm{C}(\mathrm{sec})$ \\ $J:$ Welding heat-input $(\mathrm{J} / \mathrm{cm})$ \\ $t$ :Thickness of welded member (mm) \\ $T_{0}$ : Temperature of steel before welding $\left({ }^{\circ} \mathrm{C}\right)$}

According to the Eq. 1 the time of cooling from $800 / 500{ }^{\circ} \mathrm{C}$. the results show that:

The H.I with value $13.4 \mathrm{Kj} / \mathrm{cm}$ to $25.2 \mathrm{Kj} / \mathrm{cm}$ give the cooling time range from 3 to $9.5 \mathrm{sec}$ for cooling from 800 to $500{ }^{\circ} \mathrm{C}$.

The max tensile strength value exist with applying welding with the lowest heat input, this is return to higher cooling rate that is permission to austenite crystals structure to transform to martensite during welding solidification [34].

The different relation tensile strength and the heat input is shown in Fig 4 , where the development of tensile strength value with decrease the heat input because the lower the interpass temperature effect with still small cooling time make the microstructure more fine grains .

The effect of increase the thickness of test specimens shown on the tensile test results as the thickness increase as the tensile decrease too [29] this shown on Fig 4 points 1-6 .

Although the fracture of test specimens done in weld metal zones in some test specimens but with strength values higher than the minimum value of base metal.

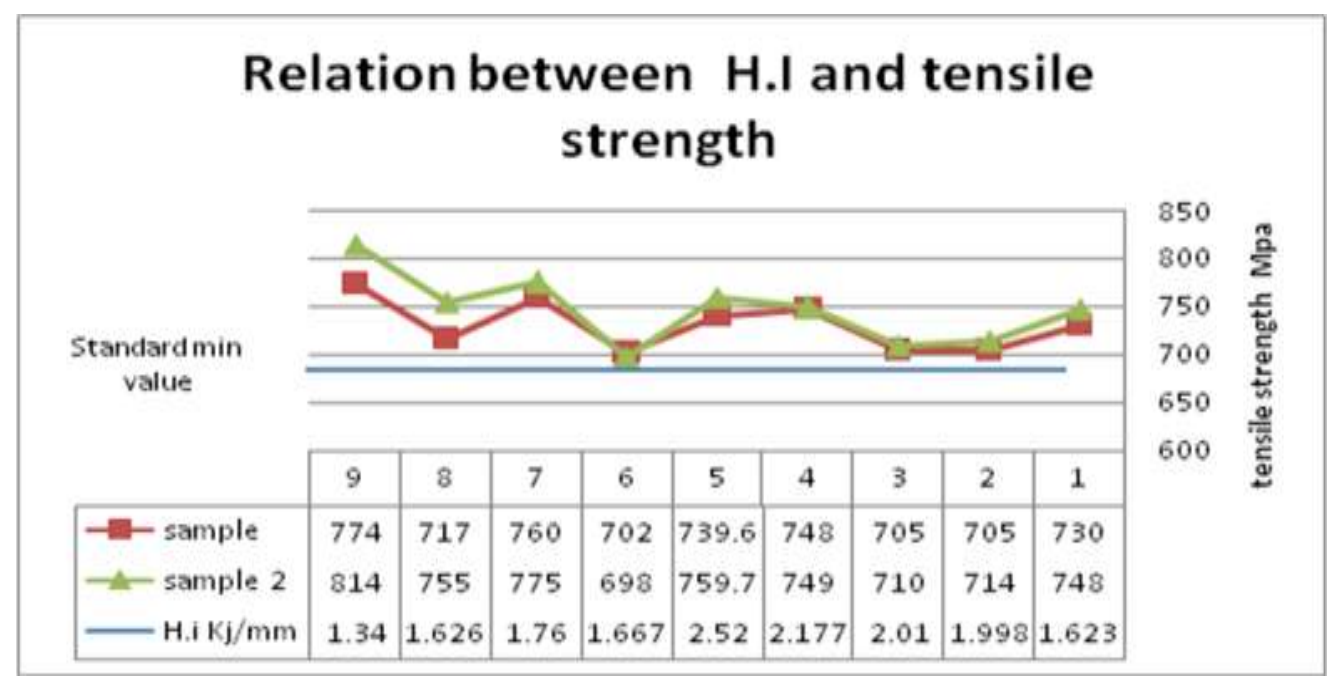

Point No 7-9----- $(6 \mathrm{~mm})$, Point No. 4-6 --- $(10 \mathrm{~mm}) \quad$, Point No 1-3 --- $(14 \mathrm{~mm})$

Fig 4 Show the effects of H.I and Interpass temperature on tensile strength of test specimens

The compared results show that heat input has a big effect on the tensile properties, with the increase of heat input, the tensile strength of welding joint only decreases .

\section{B- Notch-Toughness tests}

The Charpy V notch impact toughness data obtained at $-196{ }^{\circ} \mathrm{C}$ from the WM and HAZ regions of three weld joints welded with heat inputs levels are presented in Fig 5 which the figure with underline shows 
the average value of the impact absorbed energy. It is clear that the impact toughness of every zone of the weld joints with three different heat input levels all satisfy the demand of $27 \mathrm{~J}$ at $-196{ }^{\circ} \mathrm{C}$ as required by standard , even when the heat input is in the range of $13.4-25.2 \mathrm{~kJ} / \mathrm{cm}$.

The results of toughness in HAZ and W.M zones were increased as H.I decreased. Austenite -rich and ferrite -rich bands are formed during socking because of the re-distribution of element $\mathrm{C}, \mathrm{N}$ and $\mathrm{Ni}$ as shown in Point No 1-3. The austenite enriched of C,N and Ni is still stable [35] .

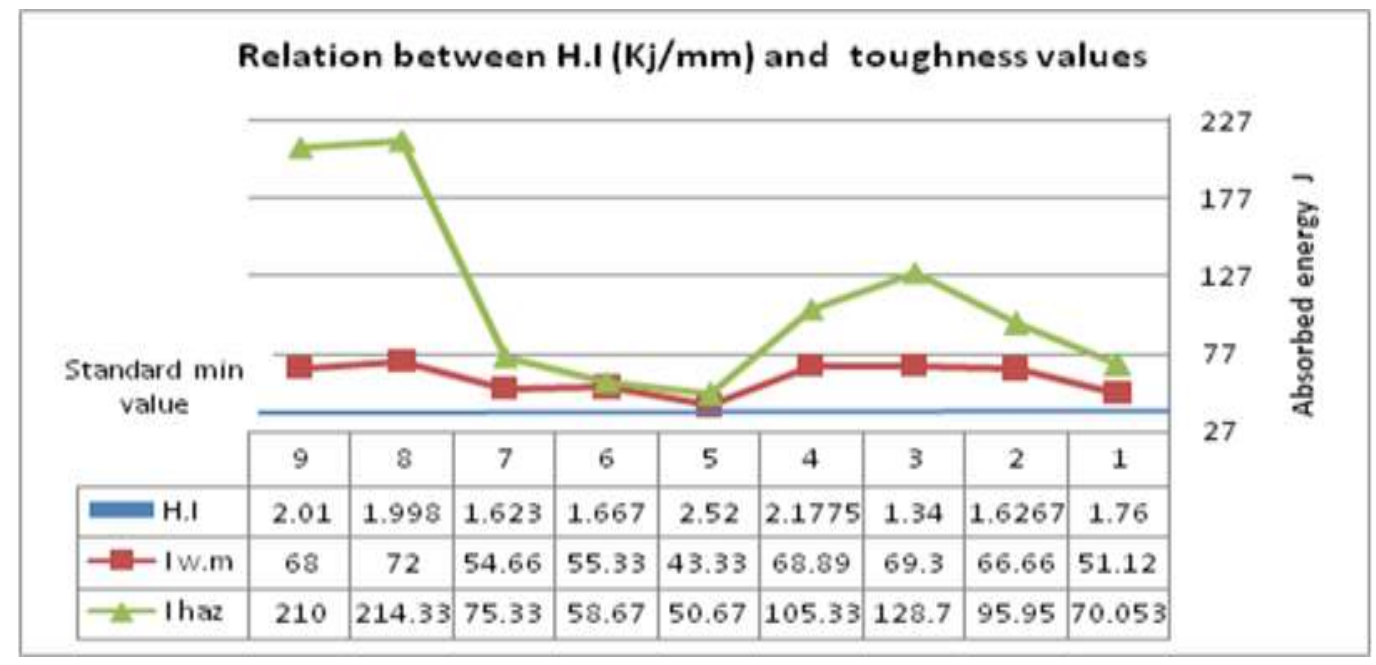

Point No 7-9----- $(14 \mathrm{~mm}) ， \quad$ point No. 4-6 --- $(10 \mathrm{~mm}) \quad$, Point 1-3No --- $(6 \mathrm{~mm})$

Fig 5 The Impact tests results of test specimens with different thickness \& different H.I.

The Max. toughness results exist in HAZ zone than the results of W.M zone where the structure of HAZ is mainly martensite and retained austenite affected by the heat input only and W.M is mainly Ni base alloy and has coarse grains .

The results of points from 4 to 9 show that the increase in H.I has increase in the value of impact energy especially in points 4,8 and 9 in HAZ and W.M this return to still the time of cooling rate is lower and the microstructure in HAZ zone is martensite and austenite with but due to the using nickel base alloy electrode (ENiCrFe4) the Ni alloy content is approximately about $60 \%$ so the weld metal pahse is austenite structure but with coarse grains. With keep consideration the effect of increase the thickness of specimens and reduce the tensile strength of base and weld metal as increase the heat input with controlling the interpass temperature at 80 ${ }^{\circ} \mathrm{C}$.

\section{C- Guided -Bend tests}

The bending test at room temperature, all test samples for $6 \& 10$ thickness were tested for root bend (R.B)and face bend (F.B)but for $14 \mathrm{~mm}$ and the bend test were side bend (S.B) .The results showed good ductility for all joints \&all were free of surface crack or any other surface defect as the following table 5.

Table 5 Present the locations and results of Bend Tests

\begin{tabular}{|c|c|c|c|c|c|c|}
\hline Thickness of & Test & Bend test & Bend test & Bend test & Bend test & Result \\
\hline \multirow[b]{3}{*}{$6 \mathrm{~mm}$} & 1 & R.B & R.B & F.B & F.B & \multirow{9}{*}{$\begin{array}{l}\text { No surface } \\
\text { defect found }\end{array}$} \\
\hline & 2 & R.B & R.B & F.B & F.B & \\
\hline & 3 & R.B & R.B & F.B & F.B & \\
\hline \multirow[b]{3}{*}{$10 \mathrm{~mm}$} & 1 & R.B & R.B & F.B & F.B & \\
\hline & 2 & R.B & R.B & F.B & F.B & \\
\hline & 3 & R.B & R.B & F.B & F.B & \\
\hline \multirow[b]{3}{*}{$14 \mathrm{~mm}$} & 1 & S.B & S.B & S.B & S.B & \\
\hline & 2 & S.B & S.B & S.B & S.B & \\
\hline & 3 & S.B & S.B & S.B & S.B & \\
\hline
\end{tabular}

\section{D- Lateral tests}

As in Fig 6 the Lateral test results show that there are different relation between lateral expansion values in Weld metal(W.M) ,HAZ and heat input. Where the lateral expansion of W.M zone are decreased as H.I increased, the Lateral test results of HAZ zone are increased as H.I increased . 


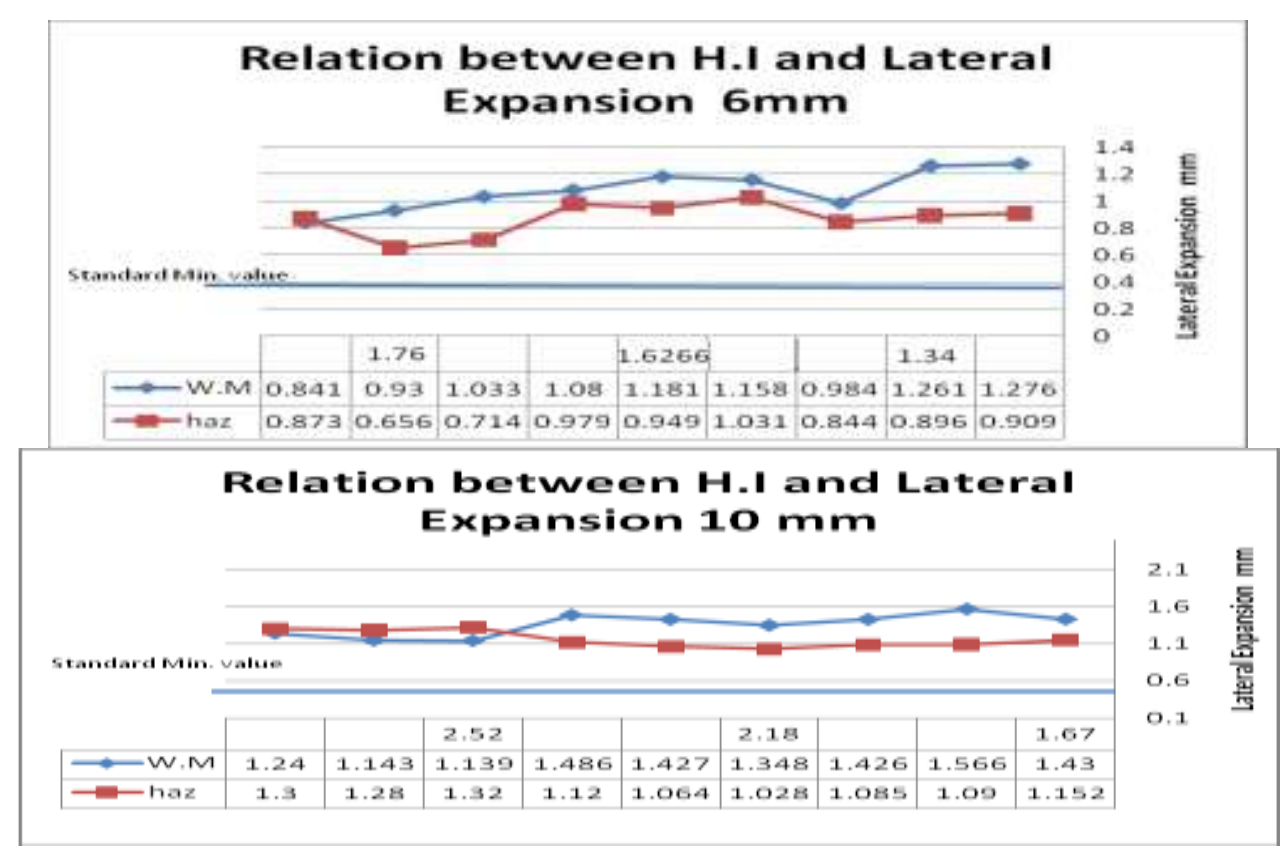

FIG 6 The Relation between H.I and Lateral expansion test of test specimens

Although as in Fig.7 the lateral expansion of W.M and HAZ zone are increased as H.I increased and the values of lateral test results of HAZ are greater than the results of W.M zone .

\section{Relation between $\mathrm{H} . \mathrm{I}$ and Lateral Expansion $14 \mathrm{~mm}$}

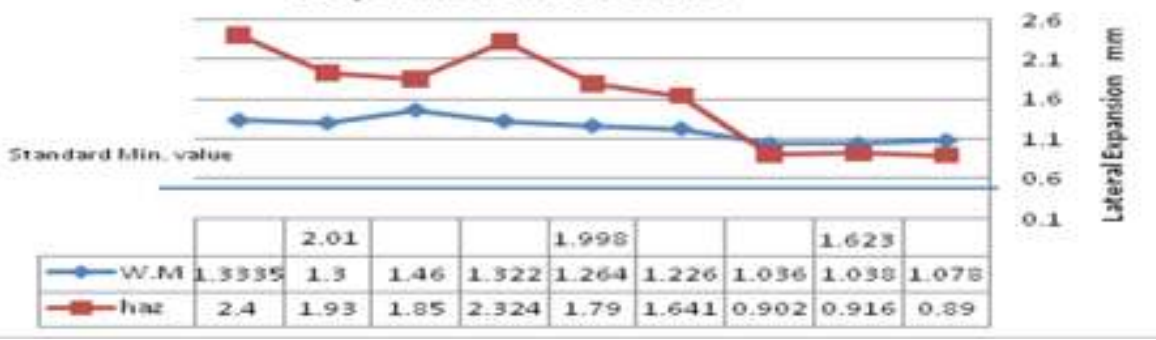

Fig 7 The Relation between H.I and Lateral expansion test of test specimens.

The all results of lateral expansion tests show that the W.M and HAZ zones are more than the value of ASME standard required $(0.38 \mathrm{~mm})$ and with average $09 \mathrm{~mm}$. This is meaning the Welded joint zones are high ductile and for the HAZ zone the structure still uniform and fine grains. The W.M zone are still low values comparing with the values of HAZ due to have a different chemical composition and the main alloy element is $\mathrm{Ni}$. The results show also the increase in lateral expansion results of test specimens increase in the cooling rate during the solidification of welded joint and increase in the yield to tensile strength ratio [36 ]

\section{Conclusion}

Based on the results achieved in this research, it can be concluded that The H.I with range value with $1.4 \mathrm{Kj}$ has a big affects on the tensile strength and toughness properties of welded joints and give a Max. values with keeping the control of interpass temperature with $80^{\circ} \mathrm{C}$ for thickness $6 \mathrm{~mm}$. It is recommend to apply H.I with no more $2.0 \mathrm{Kj} / \mathrm{mm}$ to the thickness of test specimen $10 \& 14 \mathrm{~mm}$ with keeping the interpass within $80^{\circ} \mathrm{C}$ to produce high tensile strength and toughness properties in all welded joint zones.The all range of H.I from 1.34 to above $2.0 \mathrm{Kj}$ and controlling the interpass temperature with $80^{\circ} \mathrm{C}$ has no effect on the quality and is not one of reason to create a defect in welded joint according to bend test.

The increase of thickness of test specimen play a major effect on the mechanical properties of welded joint with fixed the all other parameters (H.I and interpass temperature).The lateral expansion results confirm the effects of H.I and keeping interpass temperature with $80^{\circ} \mathrm{C}$ on the ductility of welded joint zones as the results of impact tests.Resulting values of toughness in HAZ are in all cases higher than those for the weld metal toughness, which indicates that HAZ is not the weakest place in the welded joint.Welding using the 
lowest heat input is recommended, since, in this way, lower mixture degree between filler metal and basic metals is achieved.

\section{Acknowledgements}

There have been many people who helped me to reaching this far, my sincere thanks to the My supervisors, Prof. ABD El Fatah Kourshid for giving me this great chance in life. Thanks for employees of PETROJET central workshop mechanical lab. For their help in preparing, finishing, and processing the mechanical tests.

\section{References}

[1] Shigearu Suzuki ,Yoshifumi Nakano, Keisuke Hirose,Taketo Okumura ,Hiroshi Nishikawa and Mineo Sato," Production of 9\%Ni steel plates for liquefied natural tanks ", Kawasaki steel technical report No. 6, September 1982.

[2] Manabu HOSHINO, Naoki SAITOH,Hirohide MURAOKA\& Osamu SAEKI ," Development of Super-9\%Ni Steel Plates with Superior Low-Temperature Toughness for LNG Storage Tanks ", NIPPON STEEL TECHNICAL REPORT No. 90 July 2004 .

[3] Jörgen Strömberg, Susan Sun-Hi Pak, Cost efficient LNG storage tank constructed by High productivity welding , ESAB ,PO-30..

[4] Jang-Bog Ju, Woo-sik Kim, Jae-il Jang, , Variations in DBTT and CTOD within weld heat-affected zone of API X65 pipeline steel, journal of Materials Science and Engineering A, 2012.

[5] LEI Ming ,Guo Yunyi," Formation of precipitated austenite in 9\%Ni steel and it s performance at cryogenic temperature ",ACTA Metallurgica sinica (english edition), Series A,Vol 2 No. 4 pp-244-248, Jul 1989.

[6] K,Hickmann, A.Kern, U. Schriever and J.Stumpfe, "Production and properties of high strength nickel alloy steel plates for low temperature applications ",2005.

[7] NISHIDA Shun-ichi, MATSUOKA Toshio \& WADA Tsunemi" Technology and Products of JFE Steel's Three Plate Mills",JFE TECHNICAL REPORT No. 5 , Mar. 2005LEI

[8] C.K.Syn, B.Fultz and J.W.Morris ," Mechanical stability of retained austenite in tempered 9Ni steel",ASM ans The Metallurgical society of AIME, Vol 9A,Nov 1978-1635.

[9] S O H K I T A, Control of Strength and toughness in weld metals, Welding International 200317 (9) $693-698$.

[10] C. Thaulowa,*, M. Haugea, Z.L. Zhanga, é. Ranestada, F. Fattorini , On the interrelationship between fracture toughness and material mismatch for cracks located at the fusion line of weldments, Engineering Fracture Mechanics 64 (1999) $367 \pm 382$.

[11] Toyoda M, Thaulow C, Blauel JG. Strength mis-matching and its in ${ }^{-}$uence on the performance of welded structures. In: Schwalbe K-H,Kocak M, editors. Int. Symp. Mis-Matching of Welds. ESIS Publ 17, 1994. p.335-50

[12] Thaulow C, Paauw AJ, Hauge M, Toyoda M, Minami F. Fracture property of HAZ- notched weld joint with mechanical mismatching-Part II. Effect of local mechanical mis- matching on fracture initiation in steel weldment. In: Schwalbe K-H, Kocak M, editors. Int. Symp. Mis- Matching of Welds. ESIS Publ 17, 1994. p. 417-32.

[13] R.Scott Funderburk, "A look of heat input",.Welding Innovation Vol. XVI, No. 1, 1999.

[14] WANG JUAN, LI YAJIANG and LIU PENG, Effect of weld heat input on toughness and structure of HAZ of a new super-high strength steel, Bull. Mater. Sci., Vol. 26, No. 3, April 2003, pp. 301-305.

[15] Bipin Kumar Srivastava, S.P. Tewari \& Jyoti Prakash, A REVIEW on effect of arc welding parameters on mechanical behavior of ferrous metals/alloys, International Journal of Engineering Science and Technology Vol. 2(5), 2010, 1425-1432..

[16] XU Lianghong*, ZHANG Jun, and CHEN Yanqing, Effect of Heat Input on the Microstructure and Mechanical Properties of 07MnCrMoVR Weld Joints, Chinese Journal of Mechanical Engineering, published electronically on December, 2010

[17] J.F. Lancaster, "Metallurgy of welding", 6th. Ed., Abington Publishing, 1999.

[18] J. Lancaster, "Handbook of structural welding", Abington Publishing, 1992.

[19] Norman Bailey," Weldability of Ferritic Steels", Abington Publishing, 1994.

[20] G. M. Evans and N. Bailey, "Metallurgy of basic weld metal", Abington Publishing, 1999.

[21] Mike Lord, "Interpass temperature and the welding of strong steels", Welding in the World, 41: p. 452 - 459, 1998.

[22] Tsuyoshi Takino \& Rokuro Fujimoto,"Welding technology of LNG tank", Seitetsu Kenkyu,307 (1982) ,14229 - NS-13. Kauzo Agusa,Masaaki Kosho,Noboru Nishiyama,Akio Kamada \& Yoshifumi Nakano ,Matching ferritic filler MIG welding of 9\%Ni steel, Kawasaki steel technical report No. 6, September 1982.

[23] Takahiro Kubo, Akio Ohmori and Osmu Tanigawa," Properties of high toughness 9\% Ni heavy section steel plate and its applicability to 200 000K/LNG storage tak",Kawasaki steel giho ,30, 1998 ,167-KW-20.Sakino Yoshihiro ,Horikawa

[24] Kohsuke\&Kamura Hisaya, Welding heat input limit rolled steels for building structures based on simulated HAZ tests ,trans.JWRI,Vol.30(2001)No.1.

[25] Jörgen Strömberg, ESAB AB, Göteborg, Sweden," Welding spherical tanks made of 9\% nickel steel by TISSOT in France", Svetsaren-ESAB Vol. 56 - No. 2-3,2001.

[26] Jae-il Jang, Baik-Woo Lee, Jang-Bog Ju, Dongil Kwon\& Woo-sik Kim, Effects of microstructural change on fracture characteristics incoarse grained heat-affected zones of QLT-processed 9\% Ni steel, Materials Science and Engineering A340 (2003) 68 _ 79

[27] Aleksandar Bukvić, Zijah Burzić, Radica Prokić-Cvetković, Olivera Popović, Meri Burzić\& Ratko Jovičić, Welding technology selection effect on fracture-toughness parameters of BI-material welded joints, Technical Gazette 19, 1(2012), 167-174.

[28] Jae-il Jang, Baik-Woo Lee, Jang-Bog Ju, Dongil Kwon\& Woo-sik Kim, Effects of microstructural change on fracture characteristics in coarse grained heat-affected zones of QLT-processed 9\% Ni steel, Materials Science and Engineering A340 (2003) 68 _ 79

[29] K. Hickmann, A. Kern, U. Schriever and J. Stumpfe, "Production and properties of high-strength nickel-alloy steel plates for low temperature application" www .thyssenkrupp.com/documents/Publikationen/ Techforum/ techforum_1_2009_en.pdf.

[30] ASME Sec II part A," Ferrous Material Specifications ",Ed ,2010

[31] ASME Sec II part C " Specifications for Welding Rods, Electrodes, and Filler Metals ", ED 2010

[32] ASME Sec IX, "Qualification standard for welding and brazinf procedures, welders, brazers , and welding and brazing operators", Ed 2010.

[33] Sakino Yoshihiro ,Horikawa Kohsuke\&Kamura Hisaya ,Welding heat input limit rolled steels for building structures based on simulated HAZ tests ,trans.JWRI,Vol.30(2001)No.1.

[34] Ph Bourges, M. Malingraux, el," Fabrication and welding of thick plates in 9\% NI cryogenic steel ", INDUSTEEL Co. 2008 .

[35] ESAB,Welding liquid natural gas tanks and vessels in 5\% and 9\% nickel steels, Printed in Sweden, SG idé \& tryck ab, Göteborg 11 2001/17153,

[36] ArcelorMittal USA," Plate 9\% Nickel Steel: For use at cryogenic temperatures",December 2010, www.arcelormittal.com . 